\title{
6-Phosphofructo-2-Kinase/Fructose-2,6-Bisphosphatase mRNA Expression in Streptozotocin-diabetic Rats
}

\author{
V.G. Mykhalchenko' ${ }^{1}$ K.Tsuchihara ${ }^{2}$, D. O. Minchenko', H. Esumi², O.M. Prystupiuk ${ }^{3}$, \\ O.H. Minchenko ${ }^{1 *}$
}

\author{
${ }^{1}$ Palladin Institute of Biochemistry National Academy of Sciences of Ukraine \\ 9 Leontovycha St., Kyiv 01601, Ukraine \\ ${ }^{2}$ Research Center for Innovative Oncology, National Cancer Center Hospital East, Kashiwa, Japan; \\ 6-5-1 Kashiwanoha, Kashiwa, Chiba, 277-8577, Japan \\ ${ }^{3}$ National O.O. Bohomoletz Medical University \\ 13 Bulv. Shevchenko, Kyiv 01601, Ukraine \\ e-mail: ominchenko@yahoo.com \\ * - Foreign Research Fellow of the Foundation for Promotion of Cancer Research, Tokyo.
}

We have demonstrated that changes in the expression
6-phosphofructo-2-kinase/fructose-2, 6-bisphosphatase (PFKFB) $m R N A$ in streptozotocin-diabetic rats
vary in different organs. The expression of different splice variants of PFKFB-3 mRNA is organ specific and
changes in diabetes. We have identified a new splice variant of PFKFB-3 mRNA which has catalytic
domains identical to those of the main isoform and other alternative splice variants of PFKFB-3 but differs
by the length of C-terminus. The results of this investigation support a possible role of PFKFB-3 isozymes in
adaptation of the cells to disordered carbohydrate metabolism resulting from the insulin deficiency.

Key words: PFKFB-3 mRNA; alternative splicing, lung, brain, heart, diabetes, rats.

Introduction. The homodimeric bifunctional enzyme 6-phosphofructo-2-kinase(EC 2.7.1.105); fructose-2,6-bisphosphatase(EC 3.1.3.46) (PFKFB) is a key enzyme in the regulation of glycolysis as well as gluconeogenesis in normal and different pathological conditions, in particular in diabetes mellitus and malignant tumors $[1-6]$. PFKFB controls the cellular level of fructose-2,6-bisphosphate, because one part of this enzyme has kinase activity and catalyses its synthesis while the other part is responsible for the dephosphorylation of fructose-2,6-bisphosphate [7, 8].

(C) V.G. MYKHALCHENKO, K.TSUCHIHARA, D. O. MINCHENKO, H. ESUMI, O.M. PRYSTUPIUK, O.H. MINCHENKO, 2008
Fructose-2,6-bisphosphate is considered to be a key regulator of the glycolysis because it is an allosteric activator of 6-phosphofructo-1-kinase, a key enzyme of glycolysis $[9,10]$. Hypoxia is the major activator of glycolysis; it enhances the expression of glycolytic enzymes, glucose transporters as well as PFKFB, which is responsible for the regulation of glycolysis and gluconeogenesis via induction of hypoxia inducible transcription factor HIF $[11,12]$. Enhanced glycolysis is also observed in malignant tumors. The elevated glycolytic rate is partly caused by the hypoxic conditions in the tumor and mainly determined by hypoxia inducible factor HIF even in the conditions of normal oxygen tension [13-15]. The intensity of 
glycolysis also significantly changes in diabetes mellitus as a result of disordering of glucose metabolism [16-18].

It is known that characteristics of glycolysis in different organs and tissues are possibly determined by specificity of the expression of four genes PFKFB [1,2] which changes in hypoxia and in malignant tumors but the significance of these responses depends on organ and cell types $[11,14,15]$.

Recently the expression of more than one isoform of PFKFB in different tissues has been shown [15]. Moreover, each mRNA encoded by $p f k f b l-4$ genes has two or more alternative splice variants [1, 8, 18-21]. The $p f k f b 3$ gene encoded synthesis of PFKFB ubiquitously expressed in different organs and tumor cells and has high ratio of kinase to bisphosphatase, contributes to the accumulation of fructose-2,6-bisphosphate and enhances glycolysis [11, $18,19]$. The main isoform of human PFKFB-3 mRNA has no exon $15^{\text {th }}[1,16,17]$ but recently its splice variant with exon $15^{\text {th }}$ (23 nucleotides) has been identified [18]. It was shown that this variant of PFKFB-3 had shorter and modified C-terminus and was highly expressed in cancer cells [19].

It is possible that the enhanced expression of PFKFB-3 in malignant tumors contributes to de novo nucleic acids synthesis in tumor cells and provides a potential mechanism to explain the apparent coupling of enhanced glycolysis and cell proliferation [3, 19]. Moreover, several additional alternative splice variants of PFKFB-3 mRNA with variable C-terminus were identified which differ from main isoform $[20,21]$.

The $p f k f b 1$ gene was the main object in investigation of the glycolytic regulatory mechanisms in diabetes mellitus $[5,6]$. It was shown that the expression of PFKFB-1 significantly changes in rat liver in experimental diabetes mellitus. Moreover, it was also shown that the decreasing of fructose-2,6-bisphosphate leads to hyperglycemia and insulin resistance $[5,6,22]$. The enhanced expression of PFKFB-1 or increased fructose-2,6-bisphosphate levels decrease blood glucose as a result of suppressing glucose synthesis in rat liver and restore insulin resistance [23]. There is only one publication concerning the insulin effect on the expression of PFKFB-3: insulin enhances PFKFB-3 mRNA and protein levels in cell culture of colon adenocarcinoma [24].

The expression of PFKFB-3 mRNA and its splice variants in different organs in diabetes mellitus have not been studied yet though the significance of PFKFB-3 in the regulation of glycolysis and gluconeogenesis is well known. In this work we studied the expression of PFKFB-3 mRNA in the liver, brain, testes, heart, retina and skeletal muscle as well as analyzed different isoforms of PFKFB-3 mRNA in control and diabetic rats to clarify the significance of PFKFB-3 and its splice variants in glycolysis disturbances in diabetes mellitus.

Materials and Methods. The experiments were performed with male Wistar rats (initial body weight $220-250 \mathrm{~g}$ ). Diabetes mellitus was induced by a single injection of streptozotocin ( $55 \mathrm{mg} / \mathrm{kg}$ intraperitoneally) as described previously $[25,26]$.

Experiments start in two months after injection of streptozotocin to animals. Rats with blood glucose (from tail's vein) of $14 \mathrm{mmol} / \mathrm{l}$ or more were considered diabetic. Five diabetic and five control animals were killed and their tissues frozen in liquid nitrogen for RNA extraction. Total RNA from $20-200 \mathrm{mg}$ of tissues was isolated using the acid guanidinium-phenol-chlorophorm extraction method as described previously [11]. RNA pellets were washed with $75 \%$ ethanol and dissolved in nuclease-free water.

The expression of PFKFB-3 mRNA was examined by polymerase chain reaction (PCR) of complementary DNA (cDNA). Total RNA isolated from various rat tissues was used as a template for cDNA synthesis using SuperScript II Reverse Transcriptase, ("Invitrogen", USA) and oligo(dT). Reverse transcription was performed according to the manufacturer protocol in total volume of $20 \mu \mathrm{l}$, using for reaction $0.4 \mu \mathrm{g}$ of total RNA. The amplification of PFKFB-3 cDNA ( $1 \mu 1$ of reverse transcription product which correspond to $20 \mathrm{ng}$ of total RNA used for reverse transcription) was performed using HotStarTaq Master Mix Kit ("QIAGEN", USA) and "MasterCycler Personal" ("Eppendorf”, Germany).

PCR amplification of PFKFB-3 and splice isoforms was performed using three specific for $p f k f b-3$ gene forward primers: 5'- GTCACTGCG CTGGAGCATC -3 ' (M1), 5'- 


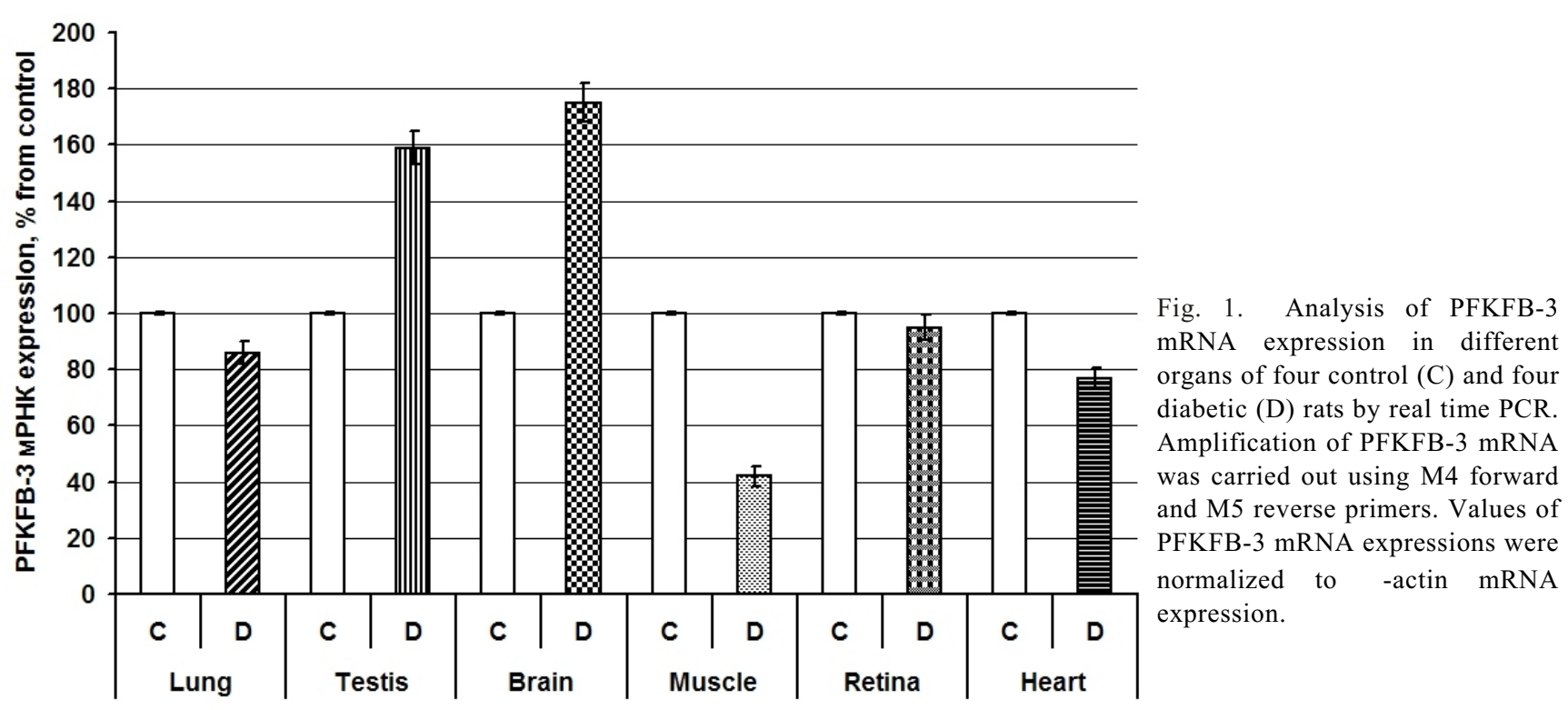

AGATGCCGTTGGAACTGACC -3' (M2) or 5'CTGGAGCCTGTGATCATGG -3' (M3) and two reverse primers: 5'- ACTTCAGCATCAGTGCTTC -3' (M6) or 5'- GGTGACACTATTGCGTCTC -3 (M7). These oligonucleotides correspond to sequences 114-132, 404-423, 1513-1531 (forward primers) and 2140-2122, 1881-1863 (reverse primers) of the published rat PFKFB-3 cDNA (GenBank accession number NM_157135), correspondently. The expression of $\beta$-actin mRNA was used as a control of analyzed RNA quantity.

The amplification of $\beta$-actin cDNA was performed using primers: forward - 5'CGTACCACTGGCATCGTGAT -3' and reverse - 5'GTGTTGGCGTACAGGTCTTT -3' [27]. The primers were received from "Sigma" or "Metabion" (Germany). The PCR products were separated by electrophoresis in agarose gel and stained with ethidium bromide. Two other primers were used for real time RCR analysis of PFKFB-3 mRNA expression: forward (M4) - 5'- TGGACGACTTCATGAAGAG $-3^{\prime}$ and reverse (M5) - 5'GCATTGGCGAACTTCTTGC -3'.

The nucleotide sequences of these primers correspond to sequences 956-974 and 1247-1229 of rat PFKFB-3 cDNA (GenBank accession number NM_157135). Quantitative PCR (qPCR) was performed on "Stratagene Mx 3000P cycler", using SYBRGreen Mix. Reaction was performed in triplicate.
Analysis of quantitative PCR was performed using special computer program "Differential expression calculator" and statistic analysis - in Excel program.

The PCR cDNA fragments were cloned in pCRII-TOPO vector according to pCRII-TOPO Kit manufacturer protocol ("Invitrogen"). DNA from clones was digested with restriction enzymes and analyzed by electrophoresis in agarose gel. cDNA fragments from selected clones were sequenced for identification of splice variants of PFKFB-3 mRNA. PCR for DNA sequencing was performed using special kit (Dye terminator cycle sequencing kit; Applied Biosystems Inc.) according to the manufacturer protocol and products were analyzed using DNA sequencing apparatus (Applied Biosystems Inc., Model 3100 , version 3.7).

Results and Discussion. The expression of PFKFB-3 mRNA was examined in the lung, testis, brain, retina, heart and skeletal muscle of control and diabetic rats by quantitative PCR using M4 forward and M5 reverse primers. The results of quantitative PCR analysis of the expression of PFKFB-4 mRNA clearly demonstrate significant increase of this mRNA expression in the brain and testes in streptozotocin diabetic rats as compared to the control animals (Fig. 1). However, no significant changes were found in PFKFB-3 mRNA expression in the retina from diabetic animals. Moreover, quantitative PCR analysis showed significant decrease of PFKFB-3 mRNA expression in 

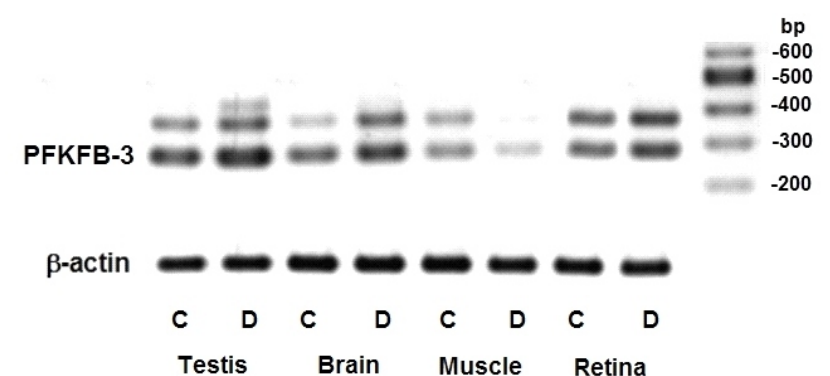

Fig. 2. Analysis of PFKFB-3 mRNA expression in different organs of control (C) and diabetic (D) rats by PCR (M3 and M7 primers) and electrophoresis amplified products in agarose gel. A representative (from five) agarose gel electrophoresis is shown.

\section{PFKFB-3}

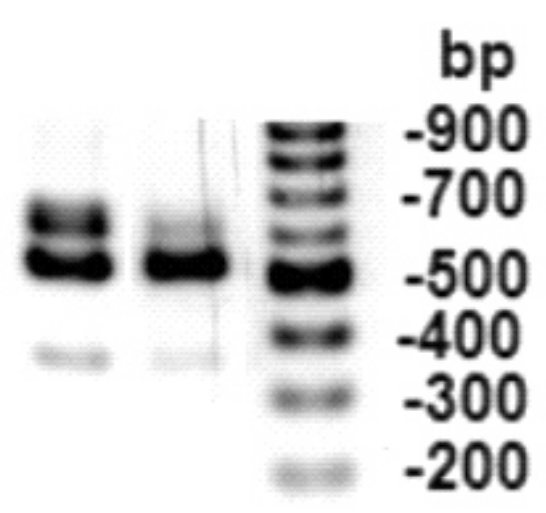

\section{$\beta$-actin}
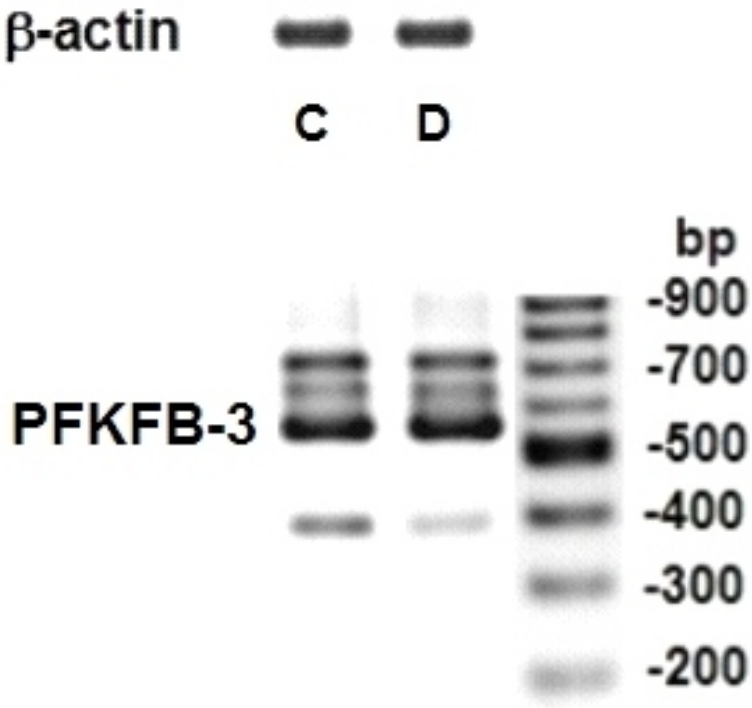

\section{$\beta$-actin}

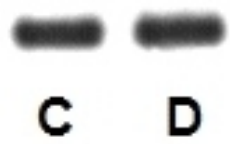

Fig. 3. Analysis of PFKFB-3 mRNA expression in the heart (a) and lung (b) of control (C) and diabetic (D) rats by PCR (M3 and M6 primers) and electrophoresis amplified products in agarose gel. A representative (from five) agarose gel electrophoresis is shown. the heart, liver and especially in skeletal muscle of streptozotocin diabetic rats as compared to the control animals (Fig. 1). Thus, there are differently directed changes in PFKFB-3 mRNA expression in different organs from rats with experimental diabetes mellitus. The quantitative PCR products were analyzed by electrophoresis in agarose gel. It is important that only one band was identified in PCR products from different control tissues as well as from diabetic animals when we used forward primer M4 and reverse primer M5. These results evidence that fragment of mRNA analyzed in this quantitative PCR is common for all known isoforms of PFKFB-3 mRNA.

Due to the fact that PFKFB-3 mRNA has several alternative splice variants $[20,21]$ we have studied its expression in different tissues of control and diabetic rats. For this purpose, we performed PCR using primers, specific for 3'-coding region of this mRNA. Two bands were identified in the brain, testes, retina and skeletal muscle of control and diabetic rats by RCR analysis with $\mathrm{M} 3$ forward and $\mathrm{M} 7$ reverse primers as was shown by electrophoretic analysis of PCR products in agarose gel (Fig. 2). Our results clearly indicate that expression of both bands increase in the brain and testes of streptozotocin diabetic rats; however, in the skeletal muscle mainly decrease in the expression of larger isoform of PFKFB-3 mRNA is observed. At the same time, three or four cDNA bands were observed in the lung and heart muscle using PCR with M3 forward and M6 reverse primers (Fig. 3, a,b). Moreover, longer amplification product is synthesized by this pair of primers as compared with M3 - M7 pair of primers because M3 - M6 pair occupies bigger part of mRNA (Fig. 2).The expression of larger isoform of PFKFB-3 mRNA significantly decreased in the heart and skeletal muscle in diabetes, but in the heart the expression of significantly shorter isoform of PFKFB-3 mRNA was shown. Its expression also decreased in the heart of streptozotocin diabetic rats. The same band of PFKFB-3 cDNA was identified in the lung. Its expression also decreased in the lung; however the expression of other bands did not change significantly in diabetes mellitus (Fig. 3, b).

To elucidate the nucleotide sequence of PFKFB-3 mRNA from different rat organs, we have carried out cDNA cloning in pCRII-TOPO vector. The clones were 
analyzed by electrophoresis in agarose gel and cloned fragments of PFKFB-3 cDNA were sequenced using M13 forward and M13 reverse primers. We isolated seven isoforms from rat tissues. Six of them were identical to the previously described [20]: one isoform has no inserts, but two isoforms have single inserts: 87 nucleotides (additional exon between exons $13^{\text {th }}$ and $14^{\text {th }}$ ) or 23 nucleotides (exon 15 $5^{\text {th }}$ ) PFKFB-3 $[16,20]$. Next two isoforms have two inserts $(87+23$ or $23+53$ nucleotides), and sixth isoform has three inserts $(87+$ $23+53$ nucleotides). 53 nucleotides insert represents additional exon located between exons $16^{\text {th }}$. Its origin is not understood. 87 nucleotides insert does not change reading frame, but add 29 amino acids, six of them are serine. This could have certain significance for regulation of enzyme activity through serine phosphorylation. Several alternative splice variants of PFKFB-3 mRNA have $15^{\text {th }}$ exon 23 nucleotides long $[18,20]$. These variants of PFKFB-3 mRNA contain different $\mathrm{C}$-terminus due to the change of reading frame. It is known that one of them intensively expresses in tumor cells [19]. It is possible that the enhanced expression of PFKFB-3 in malignant tumors contributes to the enhanced glycolysis and promotes cell proliferation [3, 19]. The PFKFB-3 mRNA isoforms whichcontain additional exon between exons $15^{\text {th }}$ a1 $6^{\text {th }}$ also have distinct $\mathrm{C}$-terminus due to the change of reading frame and have different amount and sequence position of serine residues as compared to other variants which are very important in the regulation of isozyme activity via phosphorylation. It was shown that seventh isoform is new (GenBank accession number EU034674). It is the smallest in size isoform of PFKFB-3 mRNA which has large deletion (174 nucleotides; exon 14 ${ }^{\text {th }}$ ) as compared to other variants of PFKFB-3 mRNA. It represents alternative splice variant of PFKFB-3 mRNA. Important to note, that the expression of this alternative splice variant of PFKFB-3 mRNA was decreased in the lungs and heart muscle of diabetic rats.

Thus, results shown in the Fig. 2 and 3, a, b, demonstrated tissue specific pattern of the expression of alternative splice variants of PFKFB-3 mRNA and the dependence of their expression on insulin and insulin dependent processes that occur in diabetes mellitus. The expression of PFKFB-3 mRNA was decreased in the heart and skeletal muscles but increased in the brain and testes, moreover increased expression of larger as well as smaller alternative splice variants. At the same time, in the heart and skeletal muscle the expression of larger alternative splice variants of PFKFB-3 mRNA was decreased. The larger alternative splice variants represent isoforms which have 87 nucleotides insert or two and three inserts. There are data that the liver cell proliferation and differentiation significantly depend on the expression of alternative splice variant of PFKFB-3 mRNA with 87 nucleotides insert [28]. These results demonstrate a significance of PFKFB-3 and its alternative splice variants in cell metabolism during proliferation and differentiation of cells. The results of our investigation demonstrate that alternative splicing of PFKFB-3 mRNA possibly depends on insulin. It is noteworthy, that alternative splice variants of PFKFB-3 mRNA have in C-terminus different amount and position of serine residues in amino acid sequence of PFKFB-3 that is very important in the regulation of isozyme activity via phosphorylation of serine residues [2]. Therefore, seeking for a novel isozyme is important for comprehension of tissue-specific regulation mechanisms of glycolysis.

The precise molecular mechanisms, whereby insulin participates in the regulation of alternative splicing of PFKFB-3 mRNA as well as a role of different isoenzymes in the regulation of glycolysis, await further study. PFKFB-3 should be considered a tumor-specific enzyme and its isozymes may find clinical utility as a novel targets for the development of antineoplastic agents. Important to note, that this is also significant for the diabetes treatment because the PFKFB isoforms may find clinical value for the development of antidiabetic agents for the regulation of blood glucose level [29].

Summary. The 6-Phosphofructo-2-Kinase/Fructose-2,6-Bisphosphatase mRNA expression in different organs of streptozotocin-diabetic rats was changed in different ways. The expression of different splice variants of PFKFB-3 mRNA is organ specific and changes in diabetes. We identified new splice variant of PFKFB-3 mRNA which has catalytic domains identical with main isoform and other alternative splice variants of PFKFB-3 but differs by length of C-terminus. The 
results of this investigation support a possible role of PFKFB-3 isozymes in the adaptation of cells to disturbances of carbohydrate metabolism as a result of insulin deficiency.

\section{В. Г. Михальченко, К. Тсучигара, Д. А. Минченко, Г. Есуми, А. М. Приступюк, А. Г. Минченко}

Экспрессия мРНК 6-фосфофрукто-2-киназы/фруктозо-2,6-бисфосфатазы-3 у крыс со стрептозотоциновым диабетом

Резюме

Показано, что экспрессия мРНК 6-фосфофрукто-2-киназыл/фруктозо-2,6-бисфосфатазы-3 (РFКFВ-3) в различных органах крыс с экспериментальным сахарным диабетом изменяется по-разному. Сплайс-варианты мРНК РFКFВ-3 экспрессируются в отдельных органах специфически и их экспрессия также изменяется при диабете. Выявлен новый сплайс-вариант мРНК РFКFB-3, каталитические домены в котором идентичны основной изоформе и уже известным альтернативным сплайс-вариантам РFKFB-3, отличающийся от них лишь длиной С-концевой области. Результаты проведенных исследований указывают на то, что нарушение гликолиза при стрептозотоциновом диабете может быть связано и с изменениями в экспрессии РFКFВ-3 - ключевого фермента регуляиии гликолиза.

Ключевые слова: РFКFВ-3 мРНК, альтернативный сплайсинг, стрептозотоииновый сахарный диабет, крысы.

\section{REFERENCES}

1. Rider M. H., Bertrand L., Vertommen D., Michels P. A., Rousseau G. G., Hue L. 6-phosphofructo-2-kinase/fructose2,6-bisphosphatase: head-head with a bifunctional enzyme that controls glycolysis // Biochem. J.-2004.-381, N 3.P. 561-579.

2. Bando H., Atsumi T., Nishio T., Niwa H., Mishima S., Shimizu C., Yoshioka N., Bucala R., Koike T. Phosphorylation of the 6-phosphofructo-2-kinase/fructose-2,6-bisphosphatase/ PFKFB 3 family of glycolytic regulators in human cancer // Clin. Cancer Res.-2005.-11, N 16.- P. 5784-5792.

3. Chesney J. 6-phosphofructo-2-kinase/fructose-2,6-bisphosphatase and tumor cell glycolysis // Curr. Opin. Clin. Nutr. Metab. Care.-2006.- 9, N 5.- P. 535-539.

4. Atsumi T., Nishio T., Niwa H., Takeuchi J., Bando H., Shimizu C., Yoshioka N., Bucala R., Koike T. Expression of inducible 6-phosphofructo-2-kinase/fructose-2,6-bisphosphatase/PFK FB3 isoforms in adipocytes and their potential role in glycolytic regulation // Diabetes.-2005.-54, N 12.-P. 33493357.

5. Wu C., Khan S. A., Peng L. J., Li H., Carmella S. G., Lange A. $J$. Perturbation of glucose flux in the liver by decreasing F26P2 levels causes hepatic insulin resistance and hyperglycemia // Amer. J. Physiol. Endocrinol. Metab.2006.-291, N 3.-P. E536-E543.

6. Wu C., Okar D. A., Newgard C. B., Lange A. J. Increasing fructose 2,6-bisphosphate overcomes hepatic insulin resistance of type 2 diabetes // Amer. J. Physiol. Endocrinol. Metab.-2002.-282, N 1.-P. E38-E45.

7. Rousseau G. G., Hue L. Mammalian 6-phosphofructo2-kinase/fructose-2,6-bisphosphatase: a bifunctional enzy- me that control glycolysis // Progr. Nucl. Acid Res. Mol. Biol.-1993.-45.-P. 99-127.

8. Okar D. A., Manzano A., Navarro-Sabate A., Riera L., Bartrons R., Lange A. PFK-2/FBPase 2: maker and breaker of the essential biofactor fructose-2,6-bisphosphate // Trends Biochem. Sci.-2001.-26, N 1.- P. 30-35.

9. Okar D. A., Lange A. J. Fructose-2,6-bisphosphate and control of carbohydrate metabolism in eukaryotes // Biofactors.-1999.-10, N 1.- P. 1-14.

10. Kawaguchi T., Veech R. L., Uyeda K. Regulation of energy metabolism in macrophages during hypoxia. Roles of fructose 2,6-bisphosphate and ribose 1,5-bisphosphate // J. Biol. Chem.-2001.-276, N 30.- P. 28554-28561.

11. Minchenko A. G., Leshchinsky I., Opentanova I. L., Sang N., Srinivas V., Armstead V. E., Caro J. Hypoxia-inducible factor-1-mediated expression of the 6-phosphofructo2-kinase/fructose-2,6-bisphosphatase-3 (PFKFB3) gene // J. Biol. Chem.-2002.-277, N 8.-P. 6183-6187.

12. Minchenko O. H., Opentanova I. L., Minchenko D. O., Ogura $T$., Esumi H. Hypoxia induces transcription of 6-phosphofructo-2-kinase/fructose-2,6-bisphosphatase 4 gene via hypoxia-inducible factor-1alpha activation // FEBS Lett.-2004.-576, N 1.- P. 14-20.

13. Hopfl G., Ogunshola O., Gassmann M. HIFs and tumors causes and consequences // Amer. J. Physiol.-2004.-286, N 4.-P. R608-R623.

14. Lu H., Forbes R. A., Verma A. Hypoxia-inducible factor 1 activation by aerobic glycolysis implicates the Warburg effect in cancerogenesis // J. Biol. Chem.-2002.-277, N 26.P. 23111-23115.

15. Minchenko O., Opentanova I., Caro J. Hypoxic regulation of the 6-phosphofructo-2-kinase/fructose-2,6-bisphosphatase gene family (PFKFB-1-4) expression in vivo // FEBS Lett.-2003.-554, N 3.-P. 264-270.

16. Navarro-Sabate A., Manzano A., Riera L., Rosa J. L., Ventura $F$., Bartrons $R$. The human ubiquitous 6-phosphofructo-2-kinase/fructose-2,6-bisphosphatase gene (PFKFB3): promoter characterization and genomic structure // Gene.-2001.-264, N 1.-P. 131-138.

17. Hirata T., Kato M., Okamura N., Fukasawa M., Sakakibara $R$. Expression of human placental-type 6-phosphofructo2-kinase/fructose-2,6-bisphosphatase in various cells and cell lines // Biochem. and Biophys. Res. Communs.-1998.242, N 2.- P. 680-684.

18. Chesney J., Mitchell R., Benigni F., Bacher M., Spiegel L., Al-Abed Y., Han J. H., Metz C., Bucala R. An inducible gene product for 6-phosphofructo-2-kinase with an AU-rich instability element: Role in tumor cell glycolysis and the Warburg effect // Proc. Nat. Acad. Sci. USA.-1999.-96, N 6.-P. 3047-3052.

19. Atsumi T., Chesney J., Metz C., Leng L., Donnelly S., Makita $Z$., Mitchell R., Bucala R. High expression of inducible 6phosphofructo-2-kinase/fructose-2,6-bisphosphatase-3 (iPFK-2; PFKFB3) in human cancers // Cancer Res.-2002.-62, N 20.-P. 5881-5887.

20. Watanabe F., Sakai A., Furuya E. Novel isoforms of rat brain fructose 2-phospho 2-kinase/fructose 2,6-bisphosphatase are generated by tissue-specific alternative splicing // J. Neurochem.-1997.-69, N 1.-P. 1-9.

21. Kessler R., Eschrich $K$. Splice isoforms of ubiquitous 6-phosphofructo-2-kinase/fructose-2,6-bisphosphatase in human brain // Mol. Brain Res.-2001.-87, N 2.-P. 190-195. 
22. Wu C., Okar D. A., Newgard C. B., Lange A. J. Overexpression of 6-phosphofructo-2-kinase/fructose-2, 6-bisphosphatase in mouse liver lowers blood glucose by suppressing hepatic glucose production // J. Clin. Invest.2001.-107, N 1.-P. 91-98.

23. Duran J., Navarro-Sabate A., Pujol A., Perales J. C., Manzano A., Obach M., Gomez M., Bartrons $R$. Overexpression of ubiquitous 6-phosphofructo-2-kinase in the liver of transgenic mice results in weight gain // Biochem. and Biophys. Res. Communs.-2008.-365, N 2.-P. 291-297.

24. Minchenko A. G., Stevens M. J., White L., Abatan O. I., Komjati K., Pacher P., Szabo C., Obrosova I. G. Diabetes-induced overexpression of endothelin-1 and endothelin receptors in the rat renal cortex is mediated via poly(ADP-ribose)polymerase activation // FASEB J.-2003.17.-P. 1514-1516.

25. Obrosova I. G., Minchenko A. G., Frank R. N., Seigel G. M., Zsengeller Z., Pacher P., Stevens M. J., Szabo $C$. Poly(ADP-ribose) polymerase inhibitors counteract diabetes- and hypoxia-induced retinal vascular endothelial growth factor overexpression // Int. J. Mol. Med.-2004.-14, N 1.-P. 55-64.

26. Drogat B., Auguste P., Nguyen D. T., Bouchecareilh M., Pineau R., Nalbantoglu J., Kaufman R. J., Chevet E., Bikfalvi
A., Moenner $M$. IRE1 signaling is essential for ischemia-induced vascular endothelial growth factor-A expression and contributes to angiogenesis and tumor growth in vivo // Cancer Res.-2007.-67, N 14.-P. 6700-6707.

27. Riera L., Manzano A., Navarro-Sabate A., Perales J. C., Bartrons $R$. Insulin induces PFKFB3 gene expression in HT29 human colon adenocarcinoma cells // Biochim. et Biophys. Acta.-2002.-1589, N 2.-P. 89-92.

28. Duran J., Gomez M., Navarro-Sabate A., Riera-Sans L., Obach M., Manzano A., Perales J. C., Bartrons $R$. Characterization of a new liver- and kidney-specific pfkfb3 isozyme that is downregulated by cell proliferation and dedifferentiation // Biochem. and Biophys. Res. Communs.2008.-367, N 4.-P. 748-754.

29. Wu C., Okar D. A., Kang J., Lange A. J. Reduction of hepatic glucose production as a therapeutic target in the treatment of diabetes // Curr. Drug Targets Immune Endocrinol. Metabol. Disord.-2005.-5, N 1.-P. 51-59.
UDC 577.112:616

Received 26.02.08 